\title{
Batswana female managers' career experiences and perspectives on corporate mobility and success
}

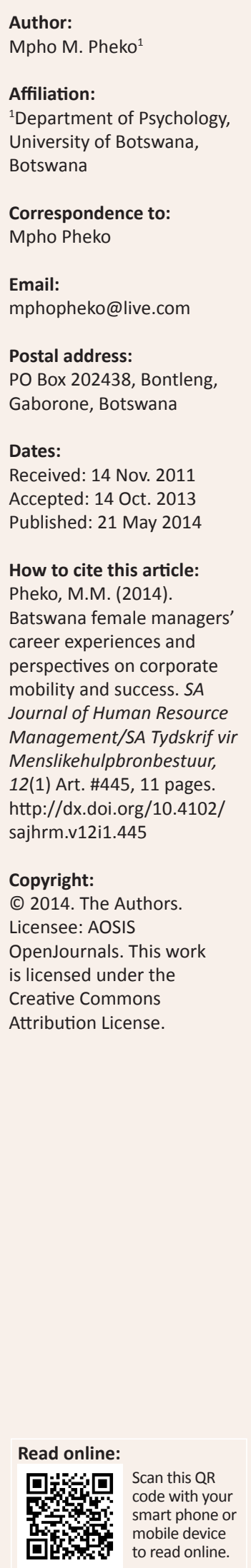

Orientation: Corporate mobility remains elusive for female managers.

Research purpose: To investigate Batswana female managers' strategies for entering and succeeding in managerial positions, the challenges they face and the consequences of success.

Motivation for the study: There is a lack of research into the way Batswana female managers obtain management positions, as well as their experiences as female managers.

Research approach, design and method: An interpretive approach using a case study strategy was employed. Semi-structured interviews were conducted which were shaped by the objectives of the study. A sample of female employees $(n=10)$, representing different organisations and professions, was obtained from various organisations in Botswana.

Main findings: Findings revealed that female managers do experience a number of challenges. Various factors were identified that accounted for their career advancement as well as the consequences of success. The consequences of success were identified as being both positive and negative.

Practical/managerial implications: The current study is important as the strategies for success that were identified can be used to assist interested women to obtain management-level positions. Furthermore, the challenges identified may assist both researchers and practitioners to design interventions that help to mitigate the challenges, in turn enabling the inclusion and advancement of women in leadership or managerial positions.

Contributions: The current study may contribute new knowledge as past research conducted in Botswana seems to have focused mainly on the impact of regulatory and legislative challenges on women's advancement. Such a focus ignores the other aspects of female managers' experiences, which are addressed by the current study.

\section{Introduction}

Gender equality, '.. as measured by comparable decision-making power, equal opportunity for education and advancement, and equal participation and status in all walks of human endeavours' (Lopez-Claros \& Zahidi, 2005, p. 2), is still a challenge for most countries, and Botswana is no exception. This disparity is even more apparent in organisations, as women remain under-represented in managerial and leadership positions (Haslam \& Ryan, 2008; International Labour Organization, 2004; Meng \& Miller, 1995; Shein, 2001; Sümer, 2006), especially the topmost positions such as senior management and chief executive officer (CEO) positions (Grant Thornton, 2012, 2013). The discrepancy is not surprising because whilst the actual numbers of female managers have almost doubled worldwide (Scott \& Brown, 2006), most women tend to get stuck in middle management positions (Cheung \& Halpern, 2010). The continuing gender disparity may also be a result of the notion that patriarchy reproduces organisational structures that give dominance to men and traditional male values (Morgan, 2006). Others, such as Sümer (2006), have described the current status as the most direct evidence of the differential treatment of men and women in the world of work.

The extent of the unbalanced representation of men and women in certain professions and in decision-making positions varies from country to country. Generally, most of the research on gender equality, gender development and gender advancement has concentrated on explaining why women are reluctant to enter certain types of career (e.g. Kelan, 2007), on the challenges experienced by women in leadership and managerial positions (e.g. Eagly \& Karau, 2002; Kelan, 2008a, 2008b; Lyness \& Thompson, 1997; Sampson \& Moore, 2008), on the number of women leading nations (e.g. Davies-Netzley, 1998; UNECA, AU \& AfDB, 2008) and on wage gaps (e.g. Agesa, Agesa \& Dabalen, 2008; Casale \& Posel, 2010; Kolev \& Robles, 2010).

Two recent studies by Grant Thornton $(2012,2013)$ revealed that in 2012, 39\% of senior management roles in Botswana were held by women, whilst in 2013,32\% of senior management 
roles in Botswana were held by women. Whilst the 2013 statistics reveal a drop from the numbers reported in 2012, they are still encouraging as the statistics position the country as one of the top 10 countries with the most women in senior management positions. The same study also revealed that in both years, (i.e. 2012 and 2013), only 3\% of the CEO positions in Botswana were held by women, revealing a misalignment between the number of female senior managers and CEOs. Because most Batswana (i.e. the people of Botswana) are employed in the civil service, one shortcoming of the report is that it only presented statistics from listed and privately held business. The statistics presented by Grant Thornton are nonetheless encouraging especially in view of the fact that since the 1995 Beijing Platform for Action, the government of Botswana has instituted a policy environment that promotes gender equality (Pheko \& Selemogwe, 2008). However, despite the headway made by listed and privately held business, the Grant Thornton findings confirm that Botswana has not yet reached $50 \%$ gender parity in wage employment (UNECA et al., 2008). Furthermore, the drop in the number of women in senior management positions between 2012 and 2013 indicates that the country may still experience challenges in reaching the $50 \%$ gender parity in wage employment, thereby making research in this area an issue worthy of investigation.

In Botswana, research seems to focus mainly on the impact of socioeconomic challenges and the existing legislation on gender development and gender equality (e.g. Mookodi, n.d., 2005; Rathapo, 2000; UNECA et al., 2008; Women's Affair Department, 1995, 1998) and on wage gaps (e.g. Siphambe \& Thokweng-Bakwena, 2001). However, some research findings suggest that societal norms and values might have more impact on an individual's career than the legal framework (Pheko, 2013a, 2013b). In this regard, Peus and Traut-Mattausch (2008) reveal that if the laws designed to support working parents are not well aligned with cultural values, they may fail to help achieve the intended objectives. Therefore, in order for research investigating the legislative and regulatory framework to produce the intended results, the research output on gender issues needs to be more diverse and more inclusive of all the factors that may facilitate or inhibit the career progression of women.

\section{Research purpose}

The main purpose of the current study was to investigate both the positive and the negative experiences of female managers in Botswana, thereby expanding the existing literature on career barriers faced by women locally and even globally. To the knowledge of the author, empirical research that considers what female managers in Botswana think about their positions is virtually non-existent. Accordingly, in an attempt to close this gap in the research, and in line with the recommendations by Ragins, Townsend and Mattis (1998), the views of female managers and executives were sought on the following issues:

- the strategies that have enabled female managers and executives to enter and succeed in middle management positions and above

- the challenges female managers face

- the consequences of their achievements.

To the knowledge of the author, the current study is the first attempt to examine both the positive and the negative experiences of women in managerial positions in Botswana. Such research is important because although laws have been enacted to prevent discrimination against women, female managers still face some obstacles in reaching the highest positions in their respective organisations (Dennis \& Kunkel, 2004; Sabharwal, 2013).

Studying women who have been able to shatter the glass ceiling offers a unique perspective on women as 'outsiders on the inside' (Davies-Netzley, 1998). In addition, the research findings may help researchers to understand whether gender differences commonly found at the lower levels of organisations exist at the higher levels of organisations as well (Lyness \& Thompson, 1997). The focus may also enable organisations and policymakers who seek to create an enabling environment for the inclusion, development, retention and advancement of women (Pheko \& Selemogwe, 2008) to understand both the positive and the negative experiences of women in managerial and leadership positions. Subsequently, an understanding of these may enhance the organisational policies on gender equity and gender development. For example, Reid, Allen, Armstrong and Riemenschneider (2010) indicate that, in organisations, the mere presence of mentorship programmes is not sufficient; mentors need to understand the range and complexity of the issues that female employees regard as challenges. The findings of the current study may reveal strategies that other women interested in management and leadership can implement when attempting to progress in their careers. The findings of the current study may also encourage organisations to reconsider and reorganise organisational cultures, succession plans, training and development policies and programmes, and general management or leadership development programmes to align them to the objective of facilitating female employees' career advancement.

\section{Literature review}

According to Ragins et al. (1998), dismantling the glass ceiling requires understanding the barriers women face in their advancement and the career strategies used by women who have successfully overcome the barriers to advancement. They further maintain that dismantling the glass ceiling requires an accurate understanding of the organisational climate in which female employees find themselves and CEO understanding of the subtle and overt barriers women face in their advancement (Ragins et al., 1998). The glass ceiling has generally been defined as the invisible barriers that exclude the majority of women from senior management positions by enabling women to see but not reach elite corporate positions (Federal Glass Ceiling Commission [FGCC], 1995; Heilman, 2001). Whilst there is vast literature examining the concept of the glass ceiling, and other concepts such as 
gender discrimination, gender stereotypes and mentorship, a thorough review of such literature is beyond the scope of the current study. The current study also does not seek to answer the question of why the percentage of female managers in Botswana is low. The literature review is organised according to the three areas of investigation (i.e. strategies that have enabled the women to enter and succeed in middle management positions and above, the challenges that female managers face and the consequences of their achievements).

\section{Strategies that enable females to enter into and succeed in elite positions}

According to Lyness and Thompson (1997, 2000), whilst much has been written about barriers to women's career advancement, there is less information available about women who have passed through the glass ceiling to attain executive positions and the factors that have facilitated their advancement. Therefore, in the current study, women were asked certain questions that were intended to provide an understanding of some of the factors that have facilitated their success. A number of researchers have used personcentred approaches (Riger \& Galligan, 1980) to explain the absence or presence of women in elite positions. Such approaches reveal that the need for power (Jenkins, 1994), a self-serving achievement style (Offerman \& Beil, 1992), warmth, friendliness, competence and directiveness (Carli \& Eagly, 2001) are some factors that may facilitate women's success. Specifically, Carli and Eagly (2001) advise that for women to be influential, they must balance agentic (i.e. the capacity for human beings to make choices and to impose those choices on the world) qualities with communal qualities. Further, research suggests that women who succeed in traditionally male-dominated fields such as management are perceived to have fewer stereotypical female attributes and have been placed in a sub-category characterised by attributes traditionally associated with men and less with women (Heilman, Block, Martell \& Simon, 1989).

Owing to the fact that individuals do not always have complete control over their working lives, some researchers have also highlighted factors that are external to women as important in facilitating their advancement. For example, factors such as developing good relationships (Lyness \& Thompson, 2000), receiving training, choosing organisations with appropriate cultures (Apospori, Nikandrou \& Panayotopoulou, 2006) and having a mentor (Anderson 2005; Apospori et al., 2006; Burke \& McKeen, 1990, 1997; Lyness \& Thompson, 2000; McCauley, 2005) have been proven to be instrumental in women's advancement. Mentors can expose their protégées to opportunities for career advancement by providing exposure, visibility, coaching and challenging assignments (Anderson, 2005). Mentors can also help the protégées increase job satisfaction (McCauley, 2005) and enhance their personal growth by building their self-confidence (Anderson, 2005). In addition, having a good track record of accomplishments (Lyness \& Heilman, 2006; Mainiero, 1994; Ragins et al., 1998) is another factor that is likely to predict career advancement for women. Lyness and Heilman (2006) report that women are more likely than their male counterparts to have received higher performance ratings prior to a promotion, showing that women's promotions could be more closely tied to job performance compared to those of men.

\section{Challenges faced by women in organisations}

There is no shortage of research investigating why women are not equitably represented in decision-making and leadership positions (e.g. Eagly \& Karau, 2002; Haslam \& Ryan, 2008; Snizek \& Neil, 1992). Chovwen (2003) notes that, whilst the twentieth century experienced an increase in the number of women in management positions, such increase did not afford women the opportunity to fully utilise their potentials. This is because most female managers reported a variety of challenges facing them within their roles and when they try to access higher positions of authority in organisations (e.g. Arvey, Rotundo, Johnson, Zhang \& McGue, 2006; Eagly \& Karau, 2002; Hewlett \& Luce, 2005; Haslam \& Ryan, 2008). Some researchers have used the glass ceiling metaphor to explain why there is a disproportionately low presence of women in top levels of management (Elacqua, Beehr, Hansen \& Webster, 2009; Elliott \& Smith, 2004; FGCC, 1995; International Labor Organization, 2004). Whilst the glass ceiling allows women to enter low positions of authority, it prevents women from entering the top positions of authority (Elliott \& Smith, 2004; FGCC, 1995). Some have explained this phenomenon by saying that the glass ceiling is based on attitudinal or organisational bias (Ragins et al., 1998); accordingly, it can be viewed as a natural consequence of gender stereotypes (Heilman, 2001).

Research suggests that employees who are mentored are more likely to have expectations of promotion and are also more likely to be promoted (Allen, Eby, Poteet, Lentz \& Lima, 2004). Despite such benefits of mentorship, some have reported that the role of managers as mentors in organisations can produce differential treatment of men and women (Elacqua et al., 2009) and can hinder female managers' performances (Davies-Netzley, 1998). For this reason, although both men and women need mentors, women have to overcome greater barriers when acquiring a mentor than do men (Apospori et al., 2006; Catalyst, 2003) and, consequently, women are not able to take equal advantage of the mentor-protégée relationship (Catalyst, 2003). Some researchers have blamed the existence of the so-called old boys' network, as it enables men even in the lower ranks to have friends amongst the upper echelons of organisations (Elacqua et al., 2009). Others have indicated that the informal manner in which most mentoring relationships are built makes them less available to women (Anderson, 2005).

Other challenges that have been proposed include sexual discrimination (e.g. Agars, 2004; Lyness \& Thompson, 1997). According to Lyness and Thompson (1997), the underlying cause of sexual discrimination is likely to be gender stereotypes. These stereotypes influence people's judgement and the way events are interpreted (Agars, 2004). In the context of organisations, men are regarded as possessing the qualities that are associated with managers and leaders, 
whilst women are not (Lyness \& Thompson, 1997; Schein, 2007). Schein, Mueller, Lituchy and Liu (1996) describe this sex-typing as the 'think manager-think male' attitude.

\section{Consequences of success for female managers}

According to Heilman:

[w]omen, quite simply, are not supposed to excel at jobs and tasks that are designated for males in our culture ... their success may be hindered by the disapproval their competence evokes because it violates prescriptive norms. (2001, p. 667)

Furthermore, women's careers have been characterised by assumptions about their commitment and capabilities (Durbin \& Tomlinson, 2010). So what happens when women do succeed in management and leadership jobs and tasks? According to Marshall (1995), women who persist in spite of opposition have experienced challenges. Even after female workers have been promoted, male senior managers may still hold stereotypical perceptions about their skills and ambitions, which may negatively affect their career progression (Haslam \& Ryan, 2008; Smithson \& Stokoe, 2005). A study conducted in Germany and the United States by Peus and Traut-Mattausch (2008) reveals that balancing a managerial career with the demands of a family remains very difficult for women in both the USA and Germany. This lack of work, life and family balance is challenging for both employers and employees because it is almost impossible for organisations to optimise employee satisfaction without considering non-work influences (Ford, Heinen \& Langkamer, 2007).

The theoretical arguments discussed above and the related empirical evidence prompt the following question: Do Batswana female managers encounter similar experiences and challenges? In view of the lack of empirical research conducted amongst women employees in Botswana, firstly to understand how they have managed to advance in their careers and secondly to understand some of the challenges that they face as a result of their career advancements, finding the answer to this question is challenging. The objective of the current study was therefore to close this apparent gap in research and to offer insights into this phenomenon.

\section{Research design \\ Research approach}

A qualitative approach was chosen for this study because this type of approach, by its nature, allows for the discovery of new variables and relationships, illustrates the influence of the social context on the chosen subjects (Shah \& Corley, 2006) and yields rich information on the underlying meaning of the data (Gable, 1994). Various approaches exist within the qualitative research framework (Atkinson, Coffey \& Delamont, 2001) and the researcher's worldview may also influence the way in which insight into people's worlds is gained. The current study used interpretative phenomenological analysis (IPA: Smith, Jarman \& Osborn, 1999) to provide guidelines for data collection and data analysis (Smith, 2004) and to explore the way participants make sense of their experiences (Chapman \& Smith, 2002). This approach generally attempts to provide understanding through the meanings that people assign to a phenomenon, giving explicit recognition to the world of humanly created meanings (Ngwenyama \& Lee, 1997). Smith (2004) further explains that the IPA approach is not prescriptive as it allows the researcher to select and adapt the methods to suit the context of the project. According to Fade (2004), IPA is both phenomenological (i.e. it allows the researcher to seek an insider perspective on the experiences of individuals) and interpretative. The approach also takes into account the fact that an individual's experience is always interpretive and that the experiences of the researcher may somewhat influence the manner in which the data are interpreted (Chapman \& Smith, 2002; Fade, 2004; Willig, 2001). Bearing the above definition of interpretive research in mind, the current study can be classified as an interpretive field study (Klein \& Myers, 1999).

\section{Research strategy}

The criteria for selection for the study were that the respondent had to be a woman and had to be at least a middle manager. Using Schuck and Liddle's (2004) definition, middle managers were conceptualised as individuals who oversee the work of others, report to higher-level managers and implement plans consistent with higher-level managers. It can therefore be stated that the study focused on a small number of Batswana women who have broken through the glass ceiling. The study offers a qualitative analysis of the women's experiences and their perspectives on corporate mobility and success in corporate Botswana. Whilst arbitrary, in the context of organisations success may be viewed as the individual's ability to use available resources to achieve both personal career goals and certain organisational goals within a specified time frame. Multiple cases were used in this study and 10 employees from six organisations were interviewed. Table 1 summarises the characteristics of the respondents.

\section{Research method}

All interviews were conducted face to face in the offices of the interviewees. The employees' work settings were the conventional modern workplaces where employees worked in either open or closed workspaces. As a result of their rank (i.e. middle management and above), all the participants had been allocated a closed workspace in which they were interviewed.

\section{Sampling}

Potential interviewees were identified by means of a combination of personal contacts, referrals from interviewees' friends and employers' networks. This technique, commonly referred to as the purposive snowballing technique, has been used successfully by other researchers to take advantage of social networks and allowing identified respondents to provide a researcher with a list of potential contacts (Thomson, 1997; Vogt, 1999). The participants were between 
the ages of 30 and 50; seven of the interviewees had master's degrees and three had at least a bachelor's degree. Two of the interviewees were in middle management, six were in senior management and two were in executive management. Five of the interviewees were married, two were engaged, one was divorced and two were single. Moreover, all of the interviewees had at least one child. The characteristics of the respondents are summarised in Table 1.

\section{Entrée and establishing research roles}

Access to the organisations was gained by asking managers for permission for the researcher to interview people in their organisations. Access was also gained by sending letters of invitation to participate in the study to personal contacts as well as referrals from interviewees' friends and coworkers. Thereafter, potential interviewees were sent brief descriptions of the research project and, subsequently, 10 agreed to participate.

\section{Data collection methods}

Face-to-face interviews were used in the current study. In the main, open-ended questions were asked, focusing on the respondents' education, qualifications and training, career experiences and aspirations, as well as the female managers' perspectives on corporate mobility and success. Accordingly, the following open-ended questions were asked to understand the strategies that the female managers use to enter and succeed in elite positions: (1) What do you think helped with your career development? (2) Are there any specific strategies that you have employed to aid in your advancement?

Secondly, to investigate the challenges faced by women in corporate Botswana, the interview respondents were asked the following questions: (1) Would you say that there have been any barriers to your career advancement? (2) What would you say are some of the challenges of working at a managerial or leadership level?

The third purpose of the current study was to understand the consequences of success for the female managers, and this was achieved by asking the following questions: (1) What have been the consequences of your career advancement? (2) How has your life changed since your career advancement?

\section{Recording of the data}

The interviewer recorded the responses and asked followup questions about the interviewees' strategies for entering and succeeding in elite positions; the challenges faced as managers and the consequences of achievement were also inquired about. The researcher recorded the interviews by making notes and, to ensure accuracy in recording the responses, the researcher also verified with the interviewees that she had understood them correctly.

\section{Data analysis}

Data analysis involved grouping responses under one of three themes, following the IPA guidelines for data analysis (Biggerstaff \& Thompson, 2008). The first step entailed organising and transcribing the data in MS Word after each interview. Thereafter all the responses were organised and compiled in a table. Specifically, all the interview questions were noted in the first column and the remaining columns were headed Respondent A to Respondent J, with all the responses being recorded under the relevant respondent and alongside the specific question. The second step entailed reading all the data, identifying related and recurring responses and then grouping and merging all the related responses into themes.

\section{Strategies employed to ensure data quality and reporting}

In line with the goals of other qualitative studies (Field \& Morse, 1985; Shenton, 2004) the goal for each interview was to allow the interviewee to accurately and comfortably describe her experiences. Therefore, each interviewee was given informed consent, which entailed informing the participants that their individual responses will not be shared with their management or their organisation and encouraging the participants to be frank and honest. This was done to ensure that the data collection sessions involved only those who were genuinely willing to take part and prepared to offer data freely. During the interview the interviewer took notes to record the responses. After the interview, all the interview scripts were numbered and the interviewer typed up the responses using the handwritten notes to confirm that the responses were accurately reflected.

\section{Findings}

The main purpose of the current study was to explore the positive and negative experiences of female managers in Botswana. Interviews were conducted to identify key themes and patterns in the experiences of the women and the results were grouped according to the following themes: (1) strategies that enable females to enter into and succeed in decision-making positions, (2) the challenges faced by the women and (3) the consequences of success for female managers.

\section{Theme 1: Strategies that enable females to enter into and succeed in elite positions}

The first observation was that whilst none of the interview respondents in the current study mentioned attaining further

TABLE 1: The characteristics of the respondents.

\begin{tabular}{|c|c|c|c|c|c|c|c|c|c|}
\hline \multirow[t]{2}{*}{ Industry type } & \multicolumn{2}{|c|}{ Highest education level } & \multicolumn{3}{|c|}{ Current level of responsibility at work } & \multicolumn{4}{|c|}{ Relationship status } \\
\hline & $\begin{array}{c}\text { Bachelor's } \\
\text { degree }\end{array}$ & $\begin{array}{c}\text { Postgraduate } \\
\text { degree }\end{array}$ & $\begin{array}{l}\text { Middle } \\
\text { manager }\end{array}$ & $\begin{array}{l}\text { Senior } \\
\text { manager }\end{array}$ & $\begin{array}{l}\text { Executive } \\
\text { manager }\end{array}$ & Single & Engaged & Married & Divorced \\
\hline Information Technology & 1 & 2 & 1 & 1 & - & 2 & - & - & - \\
\hline Human Resources & 2 & 2 & 1 & 3 & 2 & - & 2 & 3 & - \\
\hline Finance & - & 3 & - & 2 & - & - & - & 2 & 1 \\
\hline
\end{tabular}


education as a strategy for success, the biographical data gathered indicated that seven of the interviewees possessed master's degrees and three had at least a bachelor's degree. Whilst it appeared that education had been a requirement for entry into management positions for these women, all of them were oblivious to that requirement. In responding to the two questions stated above about strategies that enable females to enter into and succeed in elite positions, the interviewees revealed that hard work, intelligence and ambition were the key factors accounting for their achievements. For example, the majority of the interviewees explicitly mentioned hard work as a strategy for success. The importance of aligning hard work with goals and achievement was also mentioned by many of the interviewees. For example:

'When you are a hard worker, you understand your individual role, you understand the collective purpose and mission of your organisation, and you also understand your industry.' (Respondent F: engaged, bachelor's degree, Human Resources middle manager)

Certain of the interviewees indicated that at the beginning of each year they deliberately designed structured career and performance plans, whilst others made sure that their organisation's strategic plan became their guiding tool for performance throughout the year. Hence, for these women it would appear that the attainment of success was about having a career vision and working towards the vision. Another strategy that was mentioned by some of the interview respondents was the importance of developing and using the same career strategies as their male counterparts. The following extracts are indicative of how some of the women used this strategy:

'I also knew that it is about attitude, I have been willing to make tea as well as play football. ... The problem with some women is that they do not want to play football.' (Respondent A: single, bachelor's degree, Information Technology senior manager)

'CEOs are men; at times, it feels like they just want to surround themselves with others just like them, so you need to know the boys' way of doing things.' (Respondent B: divorced, postgraduate degree, Finance/Auditing senior manager)

'I do not understand why women want to be treated like ladies in the boardroom. They need to understand that the 'ladies first' concept works only at the dinner table.' (Respondent C: married, postgraduate degree, Human Resources, executive manager).

'Women need to be able to rise to the occasion when the need requires. Men are able to do this better than us.' (Respondent D: married, postgraduate degree, Finance/Auditing senior manager)

'I am the only woman in a family of five ... this has taught me to be tough and strong. ... Some people express that I am quite masculine, but it does not bother me.' (Respondent E: married, postgraduate degree, Finance/Auditing senior manager)

Several respondents also highlighted the need to convert challenges into opportunities for growth. For example, a woman who was overlooked for a promotion stated:

'They overlooked me and promoted a much more underqualified and incompetent man. Instead of feeling sorry for myself, I earned an MBA and was later hired for an even higher position by my former employer's competitor.' (Respondent C: married, postgraduate degree, Human Resources executive manager)

The last strategy mentioned by several women was the importance of establishing work relationships and understanding the value of the collective in achieving organisational goals. Some of them mentioned that they have great concern for their co-workers and their subordinates' welfare. For example, one respondent stated:

'While I am intolerant of non-performance from my direct reports, I always try to engage them in decision-making as I believe that every human being has something to offer. ... I also ensure that I give credit to the right individuals.' (Respondent J: married, bachelor's degree, Human Resources senior manager)

\section{Theme 2: Challenges faced by women in organisations}

Some of the respondents indicated that there are no challenges that are specific to women, whilst others did mention some challenges. One respondent, who maintains that there are no challenges specific to women, reflected:

'I do not like playing a cry baby ... for me, it seems that Batswana women have mental limits that they set for themselves.' (Respondent C: married, postgraduate degree, Human Resources executive manager)

When asked the question about the challenges of working at a managerial or leadership level one respondent stated:

'Yes, there are challenges, but they have nothing to do with gender; women like blaming industry-specific challenges on gender, it is exhausting.' (Respondent E: married, postgraduate degree, Finance/ Auditing senior manager)

In responding to the question about barriers to career advancement, a respondent provided the following response:

'In my case, I have been blocked by other women, not men ... maybe these women want to be the only ones at the top.' (Respondent J: married, bachelor's degree, Human Resources senior manager)

For those who had experienced challenges, these included difficulty in attaining work, family and life balance. Others mentioned the 'old boys' network' as one of the challenges they deal with. The following excerpts are examples of responses to the question: What would you say are some of the challenges of working at a managerial or leadership level?

'As you go up the ladder, all you see is men. So for you to succeed, you have to do it their way.' (Respondent G: single, postgraduate degree, Information Technology middle manager)

'At times I feel like I do not get the required support and buy-in because I do not drink with the boys.' (Respondent I: engaged, postgraduate degree, Human Resources executive manager)

Whilst the interviewees did not explicitly mention the lack of female mentors as a challenge to their progression, some of the responses given by the women indicated that this was a key challenge for female managers. For example: 
'It is easier for the men to progress because even some of my subordinates are friends with the big bosses, so they obviously know some of the things before me.' (Respondent I: engaged, postgraduate degree, Human Resources executive manager)

Another respondent, who expressed similar concerns, stated:

'Relationships with the right individuals at the top matters a lot, because for women, at times, it feels like having necessary knowledge and abilities is not enough.' (Respondent G: single, postgraduate degree, Information Technology middle manager)

\section{Theme 3: Consequences of success for female managers}

Almost half of the interviewees expressed their views on the positive consequences of career advancement. Several women reported that since their advancement they had received more respect from their peers, family and friends. One respondent noted:

'It has been mostly positive; suddenly, my opinion, views, and contributions matter.' (Respondent H: single, postgraduate degree, Information Technology middle manager)

Other interviewees indicated that they were better able to take care of their families, and put their children in better schools, whilst some mentioned that they were now able to live the type of lifestyle they had always desired. Some of those who discussed the negative consequences spoke of jealousy and resentment, especially from other women. One respondent stated:

'Yes, you will get blocked by other women more than men ... I think it is because other women see you becoming what they cannot be.' (Respondent J: married, bachelor's degree, Human Resources senior manager)

Some respondents mentioned having to deal with the negative stereotypes of successful women, such as:

'Some people have negative stereotypes of successful women and they will try to treat you like you are displaying the stereotypic behaviourss.' (Respondent J, married, bachelor's degree, Human Resources senior manager)

There was evidence that female managers have to prove their worth even more as they advance to higher positions. Such reflections are indicated in the following quotes:

'The "Prove your worth" game never stops. It is like, the more I advance, the more I have to prove my competency.' (Respondent I, engaged, postgraduate degree, Human Resources executive manager)

'For a woman, it will get tougher, it feels like having necessary requirements is not enough.' (Respondent J, married, bachelor's degree, Human Resources senior manager)

Several mentioned even more difficulties balancing work, family and life. The following extracts are indicative of the challenges inherent in striking a work family and life balance:

'An eight-hour day is already difficult for any working mom. But when you go up the ladder, you have to put in more hours, so just imagine.' (Respondent D: married, postgraduate degree, Finance/Auditing senior manager)

'My children have been the most impacted. One day I came home to a note from my son asking me to change my job.' (Respondent J: married, bachelor's degree, Human Resources senior manager)

'Looking at the family and work role expectations, it is easier for a husband than a wife to work and 10-15 hours a day that an executive role requires ... this is especially so for someone like me who is not an advocate for a man doing house work.' (Respondent C: married, postgraduate degree, Human Resources executive manager)

\section{Discussion}

In line with the objectives to investigate female Batswana managers' strategies for entering and succeeding in managerial positions and the challenges and consequences of success, the findings were presented. These findings provide empirical evidence that the challenges faced by female managers across the world might be more similar than different since women across the world have also reported gender stereotypes (Agars, 2004), sex discrimination (Agars, 2004; Lyness \& Thompson, 1997), as well being disproportionately represented (Elacqua et al., 2009) as some of the challenges they face. In addition, and similar to other studies, the overall findings show that most women interviewed valued education as many of them had earned a master's degree. The findings further support the views that female managers seem to depend more upon formal and objective procedures for promotion (Daley, 1996; Lyness \& Thompson, 2000). Similar to other studies, for example Mainiero (1994) and Muhr (2011), hard work, intelligence and ambition were also identified as key factors for career advancement by most of the interview respondents.

Hard work as a strategy for career advancement was emphasised by most respondents in the current study. In this regard, various researchers have offered diverse explanations for why women might need to work harder than their male counterparts. Firstly, it is a fact that women may require maternity leave as a result of their responsibilities as child bearers and primary caregivers. Therefore, when they get back to work, they may need to work harder than their male counterparts to catch up (Mainiero, 1994). The challenge of keeping up with male colleagues may also be more pronounced for women with families, as research suggests that they are more likely to retreat from the labour market than single women (Verbakel \& De Graaf, 2008). Furthermore, their roles as primary caregivers and the competing demands of family and work may disadvantage women more than men particularly looking at research that suggests that for married couples, the husband's career is still commonly regarded as being of primary and greater importance than the wife's career (Bartley, Blanton \& Gilliard, 2005; Rogers \& Amato, 2000). Others have argued that gender socialisation and gender stereotypes have led to a situation where traditional male qualities or tendencies such as assertiveness, material success, toughness, ambition and independence (Hofstede, 2001; Wood \& Lindorff, 2001) are associated with 
effective leadership. Owing to this association, women may need to work harder than their male counterparts to gain the same recognition and respect as leaders or to be promoted into leadership positions (Mainiero, 1994; Muhr, 2011).

Unlike in other studies, in the current study only one respondent attributed her success to factors such as organisational culture, organisational structures and specific programmes such as mentorship programmes. Research has generally highlighted the benefits of mentorship programmes for career advancement for women (Anderson, 2005; Apospori et al., 2006; Burke \& McKeen, 1990, 1997; Catalyst, 2003; Gordon \& Whelan-Berry, 2004; Lyness \& Thompson, 2000; McCauley, 2005). The findings of Mainiero (1994) also suggest that accurately identifying the company's values can help female executives use their firm's corporate culture as a survival strategy. The design of the current study did not allow the researcher to establish whether the organisational factors did or did not have an impact on women's career development or advancement. Particularly because directly investigating the impact of organisational culture, structures, programmes and policies was not within the scope of the current research. Therefore, future research may be designed to specifically investigate organisational factors and their impact on Batswana women's advancement and development.

The challenges identified were found to be similar to the challenges commonly reported in the literature. For example, respondents mentioned the glass ceiling, lack of access to the 'old boys' network' and work-family-life imbalance as some of the challenges they face as female managers. These findings could therefore be explained by the view that patriarchy reproduces organisational structures that give dominance to men and the traditional male values (Morgan, 2006), consequently leading to what Cheung and Halpern (2010) refer to as a 'culture of gender'. Research conducted on seniorlevel professionals from a variety of professions in China, Hong Kong and the United States by Halpern and Cheung (2008), as cited in Cheung and Halpern (2010), showed that despite socio-political differences between the three societies, the 'culture of gender' and its related gender role expectations exerted a stronger impact on women (Cheung \& Halpern, 2010). Cheung and Halpern (2010) define the 'culture of gender' as the pan-cultural gender role norms that create opportunities and constraints for all women leaders. Other researchers have also reported that across many parts of the world, people tend to hold dissimilar beliefs about leaders and women, whilst they hold similar beliefs about leaders and men (Bosak \& Sczesny, 2011). This might consequently expose women leaders across different countries to similar stereotypes (Cheung \& Halpern, 2010). Furthermore, it has been suggested that these socialised gender roles spill over into organisational roles (Eagly \& Karau, 2002), consequently creating some challenges for women.

It was also interesting that none of the women used words such as discrimination or gender stereotypes. However, many of women indicated that in order for them to advance, they had to learn how men operate and to copy the success strategies used by their male counterparts. Past research also suggests that for women to fit into certain organisational cultures and structures, they might need to 'manage gender' (Ranson, 2005; Rubin, 1997), which may include aligning oneself with men, 'working as a conceptual man', or indirectly positioning oneself as 'one of the boys' (Ranson, 2005). These suggestions are in line with research that has shown that women who succeed in male gender-typed jobs or positions are commonly perceived as having attributes traditionally associated with men (Heilman et al., 1989). The findings are also consistent with research suggestions that in organisations, because of the stereotypical belief that women might be less successful in managerial positions (Heilman, 2001; Offerman \& Beil, 1992), women in managerial positions are forced to develop managerial styles that are acceptable to male colleagues, supervisors and subordinates (Powell, 2011; Ragins et al., 1998). Such stereotypical beliefs may negatively affect the way female managers' performance is evaluated and this may in turn negatively influence women's subsequent career success (Lyness \& Heilman, 2006).

The reported findings may also be understood in the light of the role congruity theory and the lack of fit model. According to the role congruity theory (Eagly \& Karau, 2002; Eagly, Wood \& Diekman, 2000), people tend to hold dissimilar beliefs about leaders and women, whilst they hold similar beliefs about leaders and men (Bosak \& Sczesny, 2011). Heilman's (2001) 'lack of fit' model also explains that expectations about how successful a person will be in a given position are a driving force underlying personnel decisions, such that the perceived fit between one's attributes and the specific skills and abilities can determine performance expectations. Both theories therefore explain how being a woman leader might elicit thoughts of incongruence for some individuals, including people who are responsible for recruiting top management. Other factors that have been identified as a challenge for women seeking advancement, or working as managers and leaders, include certain personality characteristics, age and even child-bearing.

Similar to the views expressed by Freeman (1990) and Kelan (2007), some of the women interviewed minimised the impact of gender on career advancement. Kelan explains that claiming to be gender-egalitarian should be understood as part of the construction of a preferred identity, as being a victim of sexism may no longer be viewed as desirable. Such lack of reference to gender might also be explained from the perspective of social identification: people who identify strongly with a group such as a management group may also espouse the group's accepted goals, attitudes, intentions and expected behaviours. For example, Tajfel and Turner (1986) suggest that individuals are more likely to identify themselves in terms of a salient social group. This may mean that the female executives identify more with being managers than with being women.

Whilst it was anticipated that the Setswana culture and its role expectations could be highlighted as some of the inhibitors of 
female career success, only one woman indicated that she is traditional in her gender role orientation. Indeed none of the other women specifically mentioned culture as a source of challenge or as a barrier to success. Omar and Ogenyi (2004) indicate that in Nigeria, cultural and social traditions may play a bigger role in determining who becomes a manager. The Nigerian culture may be similar to the Setswana culture, such that the two cultures are collectivistic and traditional in their gender role orientation. In the Setswana culture, it is commonly accepted that a woman is not supposed to lead a group (Mookodi, 2005; Pheko, 2009). Furthermore, women in traditional cultures are expected first to be daughters, wives and mothers and to obey their male counterparts (Cheung \& Halpern, 2010). Whilst culture may define social expectations in respect of men's and women's roles (Cheung \& Halpern, 2010), it is also common knowledge that culture is dynamic. Therefore, it could be expected that one's cultural orientation or gender role orientation may be affected by the work experience education, marital status or tenure of the individual concerned (Pheko, 2013b). Furthermore, because organisations also have their own cultures and expectations of success, female employees may feel compelled to adapt their cultural orientations to work expectations (Pheko, 2013b).

\section{Limitations of the study}

Whilst the importance of the current research has been mentioned, the research nonetheless has limitations. Firstly, because of time and cost constraints, only ten women were interviewed. It was also difficult to find more women middle managers who were willing to be interviewed. It is believed that the research could have benefited more from a larger pool of female managers. The study could have also benefited from reviewing other archival organisational data, such as past performance reviews of the interviewees, or even interviewing other people who have worked with the interviewees to obtain a richer perspective of the factors that can explain the managers' success and the related challenges.

\section{Suggestions for future research}

It is recommended that other researchers should carry out similar research using different designs that may allow for the inclusion of more respondents and for more variables. It is also recommended that for comparative purposes, future researchers should interview both men and women. This would allow researchers to understand whether the strategies used and the challenges faced by women are unique to women. Further, women with similar profiles (i.e. educational backgrounds, years of experience, performance reviews) who have not been able to climb the corporate ladder could be interviewed in order to establish whether they used similar strategies for success.

\section{Conclusion}

Since the 1995 Beijing Platform for Action, Botswana has taken significant measures to create a policy environment that promotes gender equality and the country has since made headway in terms of the number of women in decisionmaking positions (Grant Thornton 2012, 2013; Pheko \& Selemogwe, 2008). However, as confirmed by the Grant Thornton $(2012,2013)$ study, no country in the world has yet reached the $50 \%$ gender parity in wage employment as pointed out by UNECA et al. (2008). Furthermore, the sudden drop reported by Grant Thornton (2013) in the number of women in senior management in Botswana suggests that the environment might still be unstable for female leaders and managers. Grant Thornton's (2013) findings further support assertions that after a woman manages to break the glass ceiling, her position and reputation might be much more vulnerable (Czarniawska, 2008; Haslam \& Ryan, 2008). The findings from this study and the Grant Thornton reports may also support assertions that whilst the country's policies and laws do not discriminate on the basis of gender, women may still face discrimination because of institutional practices and social attitudes (Pheko \& Selemogwe, 2008) and expectations regarding the role and status of women within the community (Republic of Botswana \& United Nations, 2004). The challenges identified above highlight the need for research that explores the reasons for such discrepancies. As noted in the preceding sections of this document, related research in Botswana has primarily investigated regulatory and legislative challenges. Whilst such studies are worthwhile and very important, in order to address the evident gap in existing research more research is needed, using different research aims and objectives, in different organisational settings and with varying research designs, as such a variety might serve different purposes. The findings from the current study may therefore help to achieve this objective by: (1) helping researchers and practitioners understand some of the career development challenges faced by women in Botswana, (2) providing policy-makers with strategies and interventions that may be used to assist other women with similar ambitions, and (3) by providing other researchers with some research ideas, as well as (4) research questions and objectives.

\section{Acknowledgements Competing interests}

The author declares that she has no financial or personal relationship(s) that may have inappropriately influenced her in writing this article.

\section{References}

Agars, M.D. (2004). Reconsidering the impact of gender stereotypes on the advancement of women in organizations. Psychology of Women Quarterly, 28(2), 103-111. http://dx.doi.org/10.1111/j.1471-6402.2004.00127.x

Agesa, R.U., Agesa, J., \& Dabalen, A. (2008). Changes in wage distributions, wage gaps and wage inequality by gender in Kenya. Journal of African Economies, 18(3), 431-460.

Allen, T., Eby, L., Poteet, M., Lentz, E., \& Lima, L. (2004). Career benefits associated with mentoring for protégés: A meta-analysis. Journal of Applied Psychology, 89(1), 127-136. http://dx.doi.org/10.1037/0021-9010.89.1.127

Anderson, D. (2005). The importance of mentoring programs to women's career advancement in biotechnology. Journal of Career Development, 32(1), 60-73. http://dx.doi.org/10.1177/0894845305277039

Apospori, E., Nikandrou, I., \& Panayotopoulou, L. (2006). Mentoring and women's career advancement in Greece. Human Resource Development International, 9(4), 509-527. http://dx.doi/org/10.1080/13678860601032627 
Arvey, R.D., Rotundo, M., Johnson, W., Zhang, Z., \& McGue, M. (2006). The determinants of leadership role occupancy: Genetic and personality factors. The Leadership Quarterly, 17(1), 1-20. http://dx.doi.org/10.1016/j.leaqua.2005.10.009

Atkinson, P., Coffey, A., \& Delamont, S. (2001). A debate about our canon. Qualitative Research, 1(1), 5-21.

Bartley, S.J., Blanton, P.W., \& Gilliard, J.L. (2005). Husbands and wives in dual-earner marriages: Decision-making, gender role attitudes, division of household labor and equity. Marriage \& Family Review, 37(4), 69-94.

Biggerstaff, D.L., \& Thompson, A.R. (2008). Interpretative phenomenological analysis (IPA): A qualitative methodology of choice in healthcare research. Qualitative Research in Psychology 5, 173-183.

Bosak, J., \& Sczesny, S. (2011). Exploring the dynamics of incongruent beliefs about women and leaders. British Journal of Management, 22(2), 254-269. http:// dx.doi.org/10.1111/j.1467-8551.2010.00731.x

Burke, R.J., \& McKeen, C.A. (1990). Mentoring in organisations: Implications for women. Journal of Business Ethics, 9, 317-332.

Burke, R.J. \& McKeen, C.A. (1997). Not every managerial woman who makes it has a mentor. Women in Management Review, 12(4), 136-139.

Carli, L., \& Eagly, A. (2001). Gender, hierarchy, and leadership: An introduction. Journal of Social Issues, 57(4), 629-636.

Casale, D., \& Posel, D. (2010). Unions and the gender wage gap in South Africa. Journa of African Economies, 20(1), 27-59.

Catalyst. (2003). The Catalyst connection: Tips for finding a mentor. Retrieved January 2, 2011, from http://www.cpa2biz.com/Career/Tips+for+Finding+a+Mentor.htm

Chapman, E., \& Smith, J.A. (2002). Interpretative phenomenological analysis and the new genetics. Journal of Health Psychology, 7, 125-130.

Cheung, F.M., \& Halpern, D.F. (2010). Women at the top: Powerful leaders define success as work and family in a culture of gender. American Psychologist, 65(3), 182-193. http://dx.doi.org/10.1037/a0017309

Chovwen, C.O. (2003). Experience above the glass ceiling: A study of female executives. Ife Psychologia: An International Journal, 11(1), 138-146.

Czarniawska, B. (2008). Femmes fatales in finance, or women and the city Organization, 15, 2, 165-86.

Daley, D.M. (1996). Paths of glory and the glass ceiling: Differing patterns of career advancement among women and minority federal employees. Public Administration Quarterly, 20(2), 143-162.

Davies-Netzley, S. (1998). Women above the glass ceiling: Perceptions on corporate mobility and strategies for success. Gender \& Society, 12(3), 339-355.

Dennis, M., \& Kunkel, A. (2004). Perceptions of men, women, and CEOs: The effects of gender identity. Social Behaviour \& Personality: An International Journal, 32(2), 155-171.

Durbin, S., \& Tomlinson, J. (2010). Female part-time managers: Networks and career mobility. Work, Employment and Society, 24(4), 621-640.

Eagly, A.H., \& Karau, S.J. (2002). Role congruity theory of prejudice toward female leaders. Psychological Review, 109(3), 573-598. http://dx.doi.org/10.1037/0033295X.109.3.573

Eagly, A.H., Wood, W., \& Diekman, A.B. (2000). Social role theory of sex differences and similarities: A current appraisal. In T. Eckes, \& H.M. Traunter (Eds.), The developmental social psychology of gender (pp. 123-174). Mahwah, NJ: Erlbaum.

Elacqua, T.C., Beehr, T.A., Hansen, C.P., \& Webster, J. (2009). Managers' beliefs about the glass ceiling: Interpersonal and organisational factors. Psychology of Women Quarterly, 33(3), 285-294.

Elliott, J.R., \& Smith, R.A. (2004). Race, gender, and workplace power. American Sociological Review, 69(3), 365-386.

Fade, S. (2004). Using interpretative phenomenological analysis for public health nutrition and dietetic research: A practical guide. Proceedings of the Nutrition nutrition and dietetic research: A practical guide. Proceedings
Society, 63, 647-653. http://dx.doi.org/10.1079/PNS2004398

Federal Glass Ceiling Commission (FGCC). (1995). Glass Ceiling Commission - good for business: Making full use of the nation's human capital. Washington, DC: US Glass Ceiling Commission.

Field, P.A., \& Morse, J.M. (1985). Nursing Research: The Application of Qualitative Approaches. Rockville, MD: Aspen Systems.

Ford, M.T., Heinen, B.A., \& Langkamer, K.L. (2007). Work and family satisfaction and conflict: A meta-analysis of cross-domain relations. Journal of Applied Psychology 92(1), 57-80. http://dx.doi.org/10.1037/0021-9010.92.1.57

Freeman, S.J.M. (1990). Managing lives: Corporate women and social change. Amherst, MA: University of Massachusetts Press.

Gable, G. (1994). Integrating case study and survey research methods: An example in information systems. European Journal of Information Systems, 3(2), 112-126.

Grant Thornton (2012). Women in senior management: Still not enough. Grant Thornton International Business Report 2012. Retrieved August 13, 2010, from http://www.grantthornton.co.nz/Assets/documents/pubSeminars/IBR-2012women-in-senior-management.pdf

Grant Thornton (2013). Women in senior management: Setting the stage for growth Grant Thornton International Business Report 2013. Retrieved August 13, 2010 from http://www.grantthornton.ie/db/Attachments/IBR2013_WiB report final. pdf

Gordon, J., \& Whelan-Berry, K. (2004). It takes two to tango: An empirical study of perceived spousal/partner support for working women. Women in Managemen Review, 19(5), 260-273.

Halpern, D.F., \& Cheung, F.M. (2008). Women at the top: Powerful leaders tell us how to combine work and family. New York, NY: Wiley/Blackwell.
Haslam, S.A., \& Ryan, M.K. (2008). The road to the glass cliff: Differences in the perceived suitability of men and women for leadership positions in succeeding and failing organizations. Leadership Quarterly, 19, 530-546.

Heilman, M. (2001). Description and prescription: How gender stereotypes prevent women's ascent up the organisational ladder. Journal of Social Issues, 57(4), 657-674.

Heilman, M.E., Block, C.J., Martell, R.F., \& Simon, M.C. (1989). Has anything changed? Current characterizations of men, women, and managers. Journal of Applied Psychology, 74(6), 935-942. http://dx.doi.org/10.1037/0021-9010.74.6.935

Hewlett, S., \& Luce, C. (2005). Off-ramps and on-ramps. Harvard Business Review, 83(3), 43-54.

Hofstede, G.H. (2001). Culture's consequences: Comparing values, behaviors, institutions and organizations across nations. (2nd edn.). Thousand Oaks, CA: Sage.

International Labour Organization. (2004). Breaking through the glass ceiling: Women in management, good for business: Making full use of the nation's human capital: in management, good for
The Environmental Scan

Jenkins, S. (1994). Need for power and women's careers over 14 years: Structural power, job satisfaction, and motive change. Journal of Personality and Social power, job satisfaction, and motive change. Journal of Personality and
Psychology, 66(1), 155-165. http://dx.doi.org/10.1037/0022-3514.66.1.155

Kelan, E.K. (2007). 'I don't know why': Accounting for the scarcity of women in ICT work. Women's Studies International Forum, 30(6), 499-511. http://dx.doi. org/10.1016/j.wsif. 2007.09.003

Kelan, E.K. (2008a). Gender, risk and employment insecurity: The masculine breadwinner subtext. Human Relations, 61(9), 1171-1202. http://dx.doi. org/10.1177/0018726708094909

Kelan, E. K. (2008b). Emotions in a rational profession: The gendering of skills in ICT work. Gender, Work and Organisation, 15(1), 49-71.

Klein, H.K., \& Myers, M.D. (1999). A set of principles for conducting and evaluating interpretive field studies in information systems. MIS Quarterly, Special Issue on Intensive Research, (23)1, 67-93.Kolev, A., \& Robles, P.S. (2010). Addressing the gender pay gap in Ethiopia: How crucial is the quest for education parity? Journa of African Economies, 19(5), 718-767.

Lopez-Claros, A., \& Zahidi, A. (2005). Women's empowerment: Measuring the global gender gap. Geneva: World Economic Forum.

Lyness, K.S., \& Heilman, M.E. (2006). When fit is fundamental: Performance evaluations and promotions of upper-level female and male managers. Journal of Applied and promotions of upper-level female and male managers. Journal of Applie
Psychology, 91(4), 777-785. http://dx.doi.org/10.1037/0021-9010.91.4.777

Lyness, K.S., \& Thompson, D.E. (1997). Above the glass ceiling? A comparison of matched samples of female and male executives. Journal of Applied Psychology, 82(3), 359-375. http://dx.doi.org/10.1037/0021-9010.82.3.359

Lyness, K.S., \& Thompson, D.E. (2000). Climbing the corporate ladder: Do female and male executives follow the same route? Journal of Applied Psychology, 85(1) 86-101. http://dx.doi.org/10.1037/0021-9010.85.1.86

Mainiero, L.A. (1994). Getting anointed for advancement: The case of executive women. Academy of Management Executive, 8(2), 53-67.

Marshall, J. (1995). Gender and management: A critical review of research. (Special Issue). British Journal of Management, 6(6), 53-62.

McCauley, C.D. (2005). The mentoring tool. Advances in Developing Human Resources, $7,443-445$.

Meng, X., \& Miller, P. (1995). Occupational segregation and its impact on gender wage discrimination in China's rural industrial sector. Oxford Economic Papers, 47(1), 136-155.

Mookodi, D. (2005, December). Situating the legal status of women in development processes: The case of Botswana. Paper presented for the 11th CODESRIA General Assembly, Maputo, Mozambique.

Mookodi, G. (n.d.). Gender and resources: Some macro and micro level considerations. Retrieved January 27, 2007, from http://www.codesria.org/Links/conferences/ gender/MOOKODI.pdf

Morgan, S. (2006. Introduction: Writing feminist history: Theoretical debates and critical practices. In S. Morgan, (Ed.), The Feminist history reader (pp. 1-48). London, UK: Routledge.

Muhr, S.L. (2011). Caught in the gendered machine: On the masculine and feminine in cyborg leadership. Gender, Work and Organization, 18 (3), 337-357. http://dx.doi. org/10.1111/j.1468-0432.2010.00529.x

Ngwenyama, O.K., \& Lee, A.S. (1997). Communication richness in electronic mail: Critical social theory and the contextuality of meaning. MIS Quarterly, 21(2), 145-167.

Offermann, L.R., \& Beil, C. (1992). Achievement styles of women leaders and their peers: Toward an understanding of women and leadership. Psychology of Women Quarterly, 16(1), 37-56. http://dx.doi.org/10.1111/j.1471-6402.1992.tb00238.x

Omar, O., \& Ogenyi, V. (2004). A qualitative evaluation of women as managers in the Nigerian Civil Service. International Journal of Public Sector Management, 17(4), 360-373. http://dx.doi.org/10.1108/09513550410539839

Peus, C., \& Traut-Mattausch, E. (2008). Manager and mommy? A cross-cultura comparison. Journal of Managerial Psychology, 23(5), 558-575. http://dx.doi. org/10.1108/02683940810884531

Pheko, M.M. (2009). Strategies to ensure that no Motswana female leader 'starts from behind' by giving young Batswana girls a head start at primary schools. The International Journal of Learning, 16(6), 569-581.

Pheko, M.M. (2013a). The impact of resource loss and resource gain among Botswana employees: A test of the conservation of resources theory. International Journa of Business and Social Science, 4(4), 151-164. 
Pheko, M.M. (2013b). A test of the culture-performance related distress hypothesis among employees in a collectivistic culture, International Journal of Development and Sustainability, 2(2).

Pheko, M.M., \& Selemogwe, M.M. (2008). Making women empowerment a national agenda: Botswana case study. In D. Amat Sapuan, K.K. Jain \& M.S. Sandhu (Eds.) Leadership in a changing landscape (pp. 105-124). Kuala Lumpur, Malaysia: CERT Publication.

Powell, G.N. (2011). The gender and leadership wars. Organizational Dynamics, 4O(1), 1-9. http://dx.doi.org/10.1016/j.orgdyn.2010.10.009

Ragins, B., Townsend, B., \& Mattis, M. (1998). Gender gap in the executive suite: CEOs and female executives report on breaking the glass ceiling. Academy of Management Executive, 12(1), 28-42. http://dx.doi.org/10.5465/ AME.1998.254976

Ranson, G. (2005). No longer 'one of the boys': Negotiations with motherhood, as prospect or reality, among women in engineering. Canadian Review of Sociology and Anthropology, 42(2), 145-166. http://dx.doi.org/10.1111/j.1755-618X.2005. tb02459.x

Rathapo, S.B. (2000). The state of gender information in Botswana. Libri, 50(4), 302 308.

Reid, M.F., Allen, M.W., Armstrong, D.J., \& Riemenschneider, C.K. (2010). Perspectives on challenges facing women in IS: The cognitive gender gap. European Journal of Information Systems, 19(5), 526-539.

Republic of Botswana, \& United Nations (2004). Botswana Millennium Development Goals Status Report 2004: Achievements, Future Challenges and Choices. Retrieved January 02, 2011, from http://www.undp.org.bw/docs/mdg_status_ report_2004.pdf

Riger, S. \& Galligan, P.J. (1980). Women in management: An exploration of competing paradigms. American Psychologist, 35, 902-910.

Rogers, S., \& Amato, P. (2000). Have changes in gender relations affected marital quality? Social Forces, 79, 731-753.

Rubin, J. (1997). Gender, equality and the culture of organizational assessment. Gender, Work and Organization, 4(1), 24-34.

Sampson, S.D., \& Moore, L.L. (2008). Is there a glass ceiling for women in development? Nonprofit Management and Leadership, 18(3), 321-339.

Sabharwal, M. (2013). From glass ceiling to glass cliff: Women in senior executive service. Journal of Public Administration Research and Theory Advance, June, 01-29. http://dx.doi.org/10.1093/jopart/mut030

Schein, V.E. (2001). A global look at psychological barriers to women's progress in management. Journal of Social Issues, 57(4), 675-688. http://dx.doi. org/10.1111/0022-4537.00235

Schein, V.E. (2007). Women in management: Reflections and projections. Women in Management Review, 22(1), 6-18.

Schein, V.E., Mueller, R., Lituchy, T., \& Liu, J. (1996). Think manager - think male: A global phenomenon? Journal of Organizational Behavior, 17(1), 33-41. http:// global phenomenon? Journal of Organizational Behavior, 17(1), 33-41. http://
dx.doi.org/10.1002/(SICI)1099-1379(199601)17:1<33::AID-JOB778>3.0.CO;2-F

Schuck, K., \& Liddle, B.J. (2004). The female manager's experience: A concept map and assessment tool. Consulting Psychology Journal: Practice and Research, 56(2), 75-87. http://dx.doi.org/10.1037/1061-4087.56.2.75
Scott, K.A., \& Brown, D.J. (2006). Female first, leader second? Gender bias in the encoding of leadership behaviour. Organizational behaviour and human decision processes, 101(2), 230-242. http://dx.doi.org/10.1016/j.obhdp.2006.06.002

Shah, S. K., \& Corley, K.G. (2006). Building better theory by bridging the quantitativequalitative divide. Journal of Management Studies, 43(8), 1821-1835. http:// dx.doi.org/10.1111/j.1467-6486.2006.00662.x

Shenton, A.K. (2004). Strategies for ensuring trustworthiness in qualitative research projects. Education for Information, 22, 63-75.

Siphambe, H.K., \& Thokweng-Bakwena, M. (2001).The wage gap between men and women in Botswana's formal labour market. Journal of African Economies, 10(2), 127-142.

Smith, J.A. (2004). Reflecting on the development of interpretative phenomenological analysis and its contribution to qualitative research in psychology. Qualitative Research in Psychology, 1(1), 39-54. http://dx.doi. org/10.1191/1478088704qp004oa

Smith, J.A., Jarman, M., \& Osborn M. (1999). Doing interpretative phenomenological analysis. In M. Murray, \& K. Chamberlain (Eds.), Qualitative health psychology: Theories and methods (pp. 218-240). London, UK: Sage.

Smithson, J., \& Stokoe, E.H. (2005). Discourses of work-life balance: Negotiating 'gender blind' terms in organizations. Gender, Work \& Organization, 12(2), 147168. http://dx.doi.org/10.1111/j.1468-0432.2005.00267.x

Snizek, W.E., \& Neil, C.C. (1992). Job characteristics, gender stereotypes and perceived gender discrimination in the workplace. Organization studies, 13(3), 403-427. http://dx.doi.org/10.1177/017084069201300305

Sümer, H.C. (2006). Women in management: Still waiting to be full members of the club. Sex roles, 55(1-2), 63-72. http://dx.doi.org/10.1007/s11199-006-9059-2

Tajfel, H., \& Turner, J.C. (1986).The social identity theory of intergroup behavior. In W.G. Austin, \& S. Worchel (Eds.), The social psychology of intergroup relations (pp. 7-24). Chicago, IL: Nelson-Hall.

Thomson, S. (1997). Adaptive sampling in behavioural surveys. NIDA Research Monograph, 167, 296-319.

UNECA, AU, \& AfDB. (2008). Report of the Sixth African Development Forum VI. Action on Gender Equality, Women's Empowerment and Ending Violence against Women: From Commitment to Delivery. 19-21 November 2008. Addis Ababa, Ethiopia.

Verbakel, E., \& De Graaf, P.M. (2008). Resources of the partner: Support or restriction in the occupational career? Developments in the Netherlands between 1940 and 2003. European Sociological Review, 24(1), 81-95.

Vogt, W.P. (1999). Dictionary of Statistics and Methodology: A Nontechnical Guide for the Social Sciences. London, UK: Sage

Willig, C. (2001). Qualitative research in psychology: Adventures in theory and method. Buckingham: Open University Press.

Women's Affairs Department. (1995). Policy on women in development. Gaborone, Botswana: Government of Botswana.

Women's Affairs Department. (1998). Report on a review of all laws affecting the status of women in Botswana. Gaborone, Botswana: Government of Botswana.

Wood, G.J., \& Lindorff, M. (2001). Sex differences in explanations for career progress. Journal Women in Management Review, 16(4), 152-162. 